\title{
Seasonal morphodynamic classification of beaches in Necochea municipality, Buenos Aires Province, Argentina
}

\section{Clasificación morfodinámica estacional de playas del partido de Necochea, provincia de Buenos Aires, Argentina}

\author{
Alejandra Merlotto ${ }^{1,2 *}$, Germán Ricardo Bértola ${ }^{1,2}$, María Cintia Piccolo ${ }^{3,4}$ \\ ${ }^{1}$ Instituto de Investigaciones Marinas y Costeras, Consejo Nacional de Investigaciones Científicas y Técnicas \\ (CONICET). \\ 2 Instituto de Geología de Costas y del Cuaternario, Universidad Nacional de Mar del Plata. CC 722-Correo \\ Central (7600) Mar del Plata, Argentina. \\ ${ }^{3}$ Instituto Argentino de Oceanografía (IADO-CONICET). CC 804 Florida 8000 (Camino La Carrindanga \\ $\mathrm{km}$ 7.5), Edificio E1 (B8000FWB), Bahía Blanca, Argentina. \\ ${ }^{4}$ Departamento de Geografía y Turismo, Universidad Nacional del Sur, Bahía Blanca, Argentina.
}

* Corresponding author. E-mail: amerlott@mdp.edu.ar

\begin{abstract}
The seasonal morphodynamic classification of Necochea and Quequén beaches (Buenos Aires Province, Argentina) was determined. Based on 102 seasonal beach profiles and sediment sampling between February 2006 and December 2009, variations in morphology and sediment budgets of five beaches were studied. According to the dimensionless fall parameter and the relative tide range, the beaches were classified depending on their modal morphodynamic state. In Quequén, beaches presented intermediate and reflective states, whereas in Necochea they presented dissipative states. The Iribarren number showed that plunging and spilling breakers predominated in Quequén and Necochea, respectively. In winter, the beaches became more dissipative, while in summer-autumn they were more reflective. This general behavior agrees with the erosion/accretion cycles. Beach profile variability was higher in Quequén. These results have been used to elaborate the coastal management program of the area.
\end{abstract}

Key words: morphodynamics, beaches, coastal erosion, Necochea, Quequén.

RESUMEN. Se realizó la clasificación morfodinámica estacional de playas de Necochea y Quequén (provincia de Buenos Aires, Argentina). Se analizaron la morfología y las variaciones sedimentarias de cinco playas a partir de 102 perfiles topográficos estacionales y muestreos de sedimentos realizados entre febrero de 2006 y diciembre de 2009. Mediante el parámetro adimensional de asentamiento y la amplitud relativa de mareas, las playas fueron clasificadas de acuerdo con su estado morfodinámico predominante. En las playas de Quequén prevalecieron los estados morfodinámicos intermedios y reflectivos, mientras que en las de Necochea prevaleció el estado disipativo. De acuerdo con el número de Iribarren, el tipo de rompiente predominante fue en voluta en Quequén y en derrame en Necochea. Durante el invierno, todas las playas presentaron un estado más disipativo, mientras que en verano y otoño un estado más reflectivo, en concordancia con los ciclos de erosión/acreción. Las playas con mayor variabilidad morfodinámica fueron las de Quequén. Estos resultados han sido empleados en la elaboración del plan de manejo costero del área estudiada.

Palabras clave: morfodinámica, playas, erosión costera, Necochea, Quequén.

\section{INTRODUCTION}

Port construction, economic activities (industry, tourism, etc.), the expansion of cities and increase in urban waste, among other causes, have contributed to the degradation of coastal environments (Merlotto and Bértola 2009, Xue et al. 2009, Komar 2010). Moreover, coastal areas are particularly vulnerable to the effects of climate change, such as rising sea level and the intensification of storms (Regnauld et al. 2004, Fiore et al. 2009). In this sense, studies on beach evolution and behavior constitute a basic tool for appropriate urban planning and integrated coastal management.

The morphodynamic state of a beach mainly depends on the characteristics of the sediments and the incident wave

\section{INTRODUCCIÓN}

La construcción de puertos, las actividades económicas (industria, turismo, etc.), el crecimiento de las ciudades y la eliminación de sus residuos, entre otras causas, han generado importantes procesos de deterioro de los ambientes costeros (Merlotto y Bértola 2009, Xue et al. 2009, Komar 2010). Además, las áreas costeras son particularmente vulnerables a los efectos del cambio climático, como el ascenso del nivel del mar y la intensificación de las tormentas (Regnauld et al. 2004, Fiore et al. 2009). En este sentido, los estudios sobre la evolución y el comportamiento de las playas constituyen una herramienta básica para una planificación urbana adecuada y un manejo costero integral. 
climate (Wright and Short 1984). Given the complex relationships between beach processes and elements, the study of beach morphodynamics contributes to the understanding of coastal environments and their variability (Benedet et al. 2004). This information is obtained by periodically monitoring beach morphology, sediments, and wave-induced changes (Benavente et al. 2002). The most commonly used beach classification methods worldwide (Short 1996, Benedet et al. 2004, Anfuso et al. 2006, Gómez-Pujol et al. 2007, Qi et al. 2010) are the model proposed by Wright and Short (1984) to determine beach morphodynamic states, the inclusion of the effect of tidal range to this model as proposed by Masselink and Short (1993), and the surf similarity parameter or Iribarren number proposed by Battjes in 1974 (Masselink and Hughes 2003).

Wright and Short (1984) identified six types of beaches with different morphologies and behaviors based on the dimensionless fall velocity $(\Omega)$. Reflective beaches $(\Omega<1.5)$ form during low-energy wave conditions, in protected areas, and have coarse sand; the foreshore is usually uniform and steep, and waves break by surging or collapsing. Dissipative beaches $(\Omega>6)$ are flat and have a soft slope, fine or medium sand, and high spilling breakers; the surf zone is wide and can have several bars. Between the reflective and dissipative morphodynamic states there are four types of intermediate beaches. These beaches have fine to medium sands, one to two bars, a backshore with moderate morphological changes, and waves of average height. The intermediate beach states are called low tide terrace $(\Omega \approx 2)$, transverse bar and rip $(\Omega \approx)$, rhythmic bar and beach $(\Omega \approx 4)$, and longshore bar and trough $(\Omega \approx 5)$. After introducing the effect of tidal range (relative tide range, RTR) to $\Omega$, Masselink and Short (1993) defined the beach types as reflective beach $(\Omega<2$; RTR $<3)$, low tide terrace beach $(\Omega<2 ; 3<$ RTR $<15)$, barred intermediate beach $(2<\Omega<5$; RTR $<3)$, low tide bar/rip intermediate beach $(2<\Omega<5 ; 3<$ RTR $<7)$, barred dissipative beach $(\Omega>5$; RTR $<3)$, and ultra-dissipative beach $(\Omega>5 ; 3<$ RTR $<15)$. The types of breakers are classified according to the Iribarren number $(\xi)$ as spilling $(\xi<0.4)$, plunging $(0.4<$ $\xi<2)$, and surging $(\xi>2)$ (Masselink and Hughes 2003).

The purpose of classifying beaches according to their morphodynamic state is to provide a conceptual framework for studying and understanding coastal environments. This classification forms the basis for diverse research such as assessing the vulnerability of beaches to coastal phenomena like sea level rise or erosion (Kokot et al. 2004, Boruff et al. 2005), the effects of storms (Benavente et al. 2002), artificial beach nourishment, and coastal defense structures (Anfuso et al. 1999). In Argentina, few studies have been conducted on the morphodynamic state of beaches and only of some beaches in Buenos Aires Province and Patagonia (Isla et al. 2001, 2002; Bértola 2006). The coastline of Buenos Aires Province has undergone intensive urbanization since 1930 and, consequently, the natural environment has been highly modified (Merlotto and Bértola 2008). In the municipality of
El estado morfodinámico de una playa depende principalmente de las características de sus sedimentos y del clima de oleaje incidente (Wright y Short 1984). Dada la complejidad de las relaciones entre los elementos y procesos presentes en la playa, el estudio de la morfodinámica de playas favorece la comprensión del ambiente costero y su variabilidad (Benedet et al. 2004). Dicho conocimiento se obtiene mediante un monitoreo periódico de la morfología, los sedimentos y los cambios de acuerdo con el régimen de oleaje de la playa (Benavente et al. 2002). El modelo propuesto por Wright y Short (1984) para determinar el estado morfodinámico de una playa, la incorporación del efecto de las mareas a este modelo hecha por Masselink y Short (1993) y el índice de similitud del surf o número de Iribarren propuesto por Battjes en 1974 (Masselink y Hughes 2003) constituyen los métodos más utilizados para clasificar las playas en todo el mundo (Short 1996, Benedet et al. 2004, Anfuso et al. 2006, Gómez Pujol et al. 2007, Qi et al. 2010).

Wright y Short (1984) identificaron seis tipos de playa con morfologías y comportamientos diferentes a partir del parámetro adimensional de asentamiento $(\Omega)$. Las playas reflectivas $(\Omega<1.5)$ se forman bajo condiciones de oleaje poco energético, en zonas protegidas y constituidas por sedimentos gruesos; la playa frontal es usualmente uniforme y de pendiente pronunciada, y las rompientes son en surgencia y en colapso. Las playas disipativas $(\Omega>6)$ son aplanadas y tienen una pendiente suave y arenas finas o medias; la zona de deslizamiento es amplia, puede poseer varias barras, y las olas rompen en derrame con alturas considerables. Entre los estados morfodinámicos reflectivo y disipativo se reconocen cuatro tipos de playas intermedias. Estas playas están constituidas por arenas finas a medias y se caracterizan por presentar de una a dos barras, una playa distal con cambios morfológicos moderados, y alturas de ola medias. Se les denomina playa intermedia con terraza en marea baja $(\Omega \approx 2)$, playa intermedia con barra transversal y corriente de retorno $(\Omega \approx 3)$, playa intermedia con barra rítmica $(\Omega \approx 4)$ y playa intermedia con canal y barra longitudinal $(\Omega \approx 5)$. Al adicionar el efecto de las mareas (amplitud relativa de mareas, ARM) al $\Omega$, Masselink y Short (1993) definen los tipos de playa como playa reflectiva $(\Omega<2$; ARM $<3)$, playa con terraza en marea baja $(\Omega<2 ; 3<$ ARM $<15)$, playa intermedia con barra $(2<\Omega<5$; ARM $<3)$, playa intermedia con barra en marea baja y corriente de retorno $(2<\Omega<5 ; 3<$ ARM $<7)$, playa disipativa con barra $(\Omega>5$; ARM $<3)$ y playa ultradisipativa $(\Omega>5 ; 3<$ ARM $<15)$. Los tipos de rompiente se clasifican, según el número de Iribarren $(\xi)$, como en derrame $(\xi<0.4)$, en voluta $(0.4<\xi<2)$ y en surgencia $(\xi>2)$ (Masselink y Hughes 2003).

La utilidad de la clasificación de playas de acuerdo con su estado morfodinámico es brindar un marco conceptual en el que el ambiente costero puede ser estudiado y entendido. Esta clasificación, además, constituye la base para diversos estudios, como evaluaciones del riesgo de las playas a fenómenos costeros como el aumento del nivel del mar o la 
Necochea, the cities of Necochea and Quequén (fig. 1) expanded on both sides of the river Quequén Grande after Quequén port was established and its associated agroindustrial activities developed. Commercial and beach-related recreational activities followed and since 1970 the area has become an important tourist destination.

The growth of both urban centers, the creation and forestation of Miguel Lillo Park, and the increase in socioeconomic activities have altered the natural system and generated environmental problems. The construction of the port's two breakwaters at the beginning of the 20th century caused sand erosion in Quequén and sand accumulation in Necochea due to the obstruction of the littoral drift (Perillo et al. 2005). The beaches and coastal infrastructure have suffered varying degrees of damage during storms. In coastal areas where the effects of human intervention are more important, partial post-storm beach recovery can occur and the degree of erosion varies depending on the magnitude of human intervention and beach characteristics. The municipal authorities thus decided to elaborate a coastal management plan. One of the objectives was the implementation of measures to prevent and mitigate the erosion process in order to enable sustainable tourism. For this, greater knowledge of the environment and its components was needed in view of the few studies available on beach evolution and erosion in the study area (Isla et al. 1997, 2009); hence, the objective of this study was to perform a seasonal morphodymic classification of the Necochea and Quequén beaches and analyze their sedimentary variations in order to generate information for the coastal management program.

\section{MATERIALS AND METHODS}

\section{Study area}

The study area (fig. 1) is located in the Pampean plains of southern Buenos Aires Province. It extends over the Southern Dune Barrier, which consists of extensive dune fields that are totally or partially covered with natural and human-induced vegetation and subject to different levels of urbanization. Active and inactive cliffs as well as abrasion platforms occur along the coast forming mixed landforms such as inactive cliffs with eolian ramps in certain sectors. Sandy beaches unfold almost uninterruptedly.

The coastline has a SW-NE orientation, coinciding with the predominant direction of the littoral drift (Perillo et al. 2005). The tide is mixed, mainly semidiurnal, and mean tidal amplitude is $0.98 \mathrm{~m}$ (SHN 2009). Mean wind speed is $17.8 \mathrm{~km} \mathrm{~h}^{-1}$ and the winds blow predominantly from the $\mathrm{N}$ and NW (Merlotto and Piccolo 2009). Highest speeds correspond to winds from the SW and S.

The following five beaches were studied: Costa Bonita and Bahía de los Vientos in the city of Quequén, and Asilo, Kabryl, and Médano Blanco in the city of Necochea (fig. 1). Costa Bonita (fig. 2a) has a mean width of $63 \mathrm{~m}$ and a erosión (Kokot et al. 2004, Boruff et al. 2005), los efectos de las tormentas (Benavente et al. 2002), las obras de alimentación artificial de playas y el diseño de obras de defensa costera (Anfuso et al. 1999). Sin embargo, en Argentina, el estudio del estado morfodinámico de las playas es escaso y sólo se ha realizado para ciertas playas de la provincia de Buenos Aires y de la Patagonia (Isla et al. 2001, 2002; Bértola 2006). Las costas de la provincia de Buenos Aires han sido urbanizadas intensamente desde $1930 \mathrm{y}$, como consecuencia, el ambiente natural ha sido modificado significativamente (Merlotto y Bértola 2008). En el partido de Necochea, las ciudades de Necochea y Quequén (fig. 1) se desarrollaron a ambos lados del río Quequén Grande a partir de la instalación del puerto Quequén y de las actividades agroindustriales derivadas de su funcionamiento. Luego, comenzaron a desarrollarse actividades comerciales y de servicios, entre ellas el turismo de sol y playas, y el área se constituyó en un destacado centro turístico a nivel nacional desde 1970.

El crecimiento de ambos centros urbanos, la creación y forestación del parque Miguel Lillo y la intensificación de las actividades socioeconómicas han alterado el sistema natural y han generado problemas ambientales. La construcción de las escolleras de abrigo del puerto a comienzos del siglo XX ocasionó procesos de erosión en Quequén y de acumulación en Necochea, debido a la obstrucción de la deriva litoral (Perillo et al. 2005). Las playas y la infraestructura costera han sufrido diferentes grados de daño durante temporales. En las zonas costeras donde los efectos de la intervención del hombre son importantes, la reconstrucción de la playa luego de una tormenta puede realizarse en forma parcial y pueden comenzar a manifestarse procesos de erosión de diferentes grados, según la magnitud de la intervención humana y las características de la playa. En este contexto, las autoridades municipales decidieron elaborar un plan de manejo costero. Entre sus objetivos se incluyó la implementación de medidas tendientes a prevenir y mitigar el proceso erosivo para posibilitar el uso y la explotación sostenible de los recursos turísticos. Debido a ello, surgió la necesidad de incrementar el conocimiento sobre el funcionamiento del ambiente y sus componentes. Los estudios sobre la evolución de las playas y los problemas de erosión del área de estudio son escasos (Isla et al. 1997, 2009); por lo tanto, el objetivo de este trabajo fue efectuar la clasificación morfodinámica estacional de las playas de Necochea y Quequén, y analizar sus variaciones sedimentarias con la finalidad de aportar conocimientos que puedan ser utilizados en la elaboración del plan de manejo costero.

\section{MATERIALES Y MÉTODOS}

\section{Área de estudio}

El área de estudio (fig. 1) se asienta sobre la barrera medanosa austral, en la llanura pampeana del sur de la 


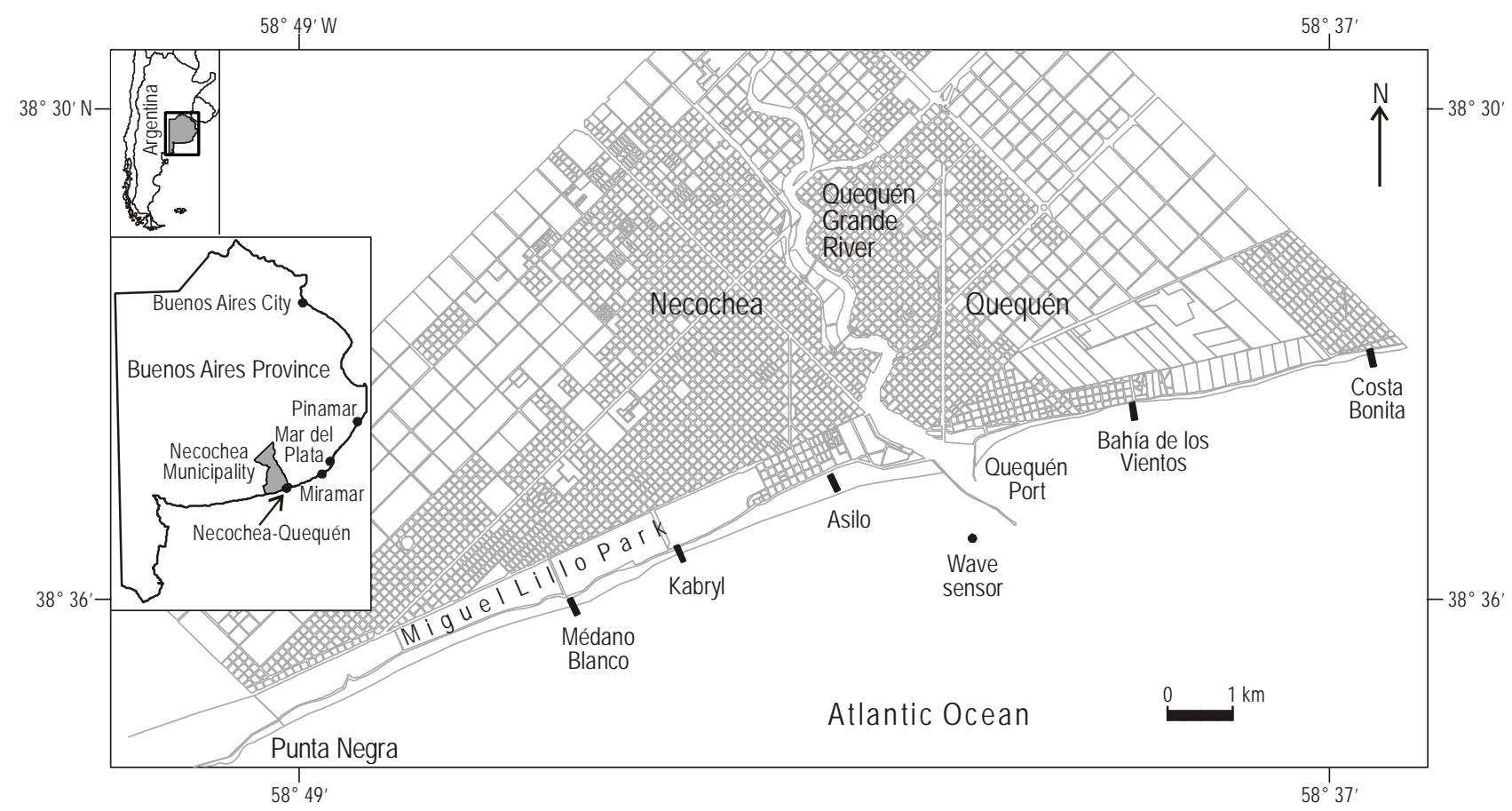

Figure 1. Location of the beaches (filled rectangles) surveyed in the municipality of Necochea, Buenos Aires Province (Argentina), and of the wave sensor operated by Consorcio de Gestión del Puerto Quequén.

Figura 1. Localización de las playas estudiadas (rectángulos negros) en el partido de Necochea, provincia de Buenos Aires (Argentina) y del sensor de oleaje del Consorcio de Gestión del Puerto Quequén.

moderate slope (4.8\%); it lies between an abrasion platform and a degraded coastal dune, and its natural dynamics have been altered by the presence of two deteriorated groins. Bahía de los Vientos (fig. 2b) is a pocket beach with a mean width of $40 \mathrm{~m}$ and a steep slope (7.7\%); it lies at the foot of an active cliff and does not present backshore development. Rip-rap defense work was carried out here parallel to the shoreline in 2009. Asilo (fig. 2c) is located in the urban sector of Necochea, $1800 \mathrm{~m}$ to the west of the southern breakwater of Quequén port; it is the most extensive beach of the area $(278 \mathrm{~m})$ and has the gentlest slopes $(2.6 \%)$. Kabryl and Médano Blanco are both located in front of Miguel Lillo Park. Kabryl (fig. 2d) has a mean width of $127 \mathrm{~m}$ and a moderate slope (3.8\%); it lies at the foot of a 4-m-high inactive cliff partially covered by forested dunes and is close to a resort that allows beach vehicle access. Médano Blanco (fig. 2e) has a moderate slope $(4.0 \%)$ and a mean width of $105 \mathrm{~m}$, and it is located at the foot of a cliff with eolian ramp; a coastal road separates the beach from a vegetated dune field of Miguel Lillo Park.

\section{Fieldwork and analysis}

Wave data were obtained from July 2006 to December 2009 by an Interocean S4 AWI current meter equipped with wave sensors. The current meter was located $400 \mathrm{~m}$ to the southwest of the Quequén southern breakwater (fig. 1) and is provincia de Buenos Aires. Esta barrera está conformada por extensos campos de médanos, cubiertos parcial o totalmente por vegetación natural e inducida y urbanizados en diferentes grados. En la costa afloran acantilados activos e inactivos y plataformas de abrasión que conforman geoformas mixtas, como acantilados inactivos con rampas eólicas, en determinados sectores. Las playas arenosas se desarrollan en forma casi ininterrumpida.

La costa presenta una orientación SW-NE, en coincidencia con la dirección predominante de la deriva litoral (Perillo et al. 2005). La marea es mixta, predominantemente semidiurna, y la amplitud media es de $0.98 \mathrm{~m}$ (SHN 2009). La velocidad media del viento es de $17.8 \mathrm{~km} \mathrm{~h}^{-1}$ y los vientos predominantes provienen del N y NW (Merlotto y Piccolo 2009). Las mayores velocidades corresponden a los vientos del SW y S.

Las cinco playas estudiadas fueron Costa Bonita y Bahía de los Vientos en la ciudad de Quequén, y Asilo, Kabryl y Médano Blanco en la ciudad de Necochea (fig. 1). Costa Bonita (fig. 2a) posee un ancho medio de $63 \mathrm{~m}$ y una pendiente de playa media (4.8\%); se desarrolla entre una plataforma de abrasión y un médano costero degradado, y su dinámica natural ha sido alterada por la presencia de dos espigones que se encuentran en deterioro. Bahía de los vientos (fig. 2b) es una playa de bolsillo que alcanza en promedio $40 \mathrm{~m}$ de ancho y tiene una pendiente pronunciada (7.7\%); se desarrolla al pie de un acantilado activo y no 

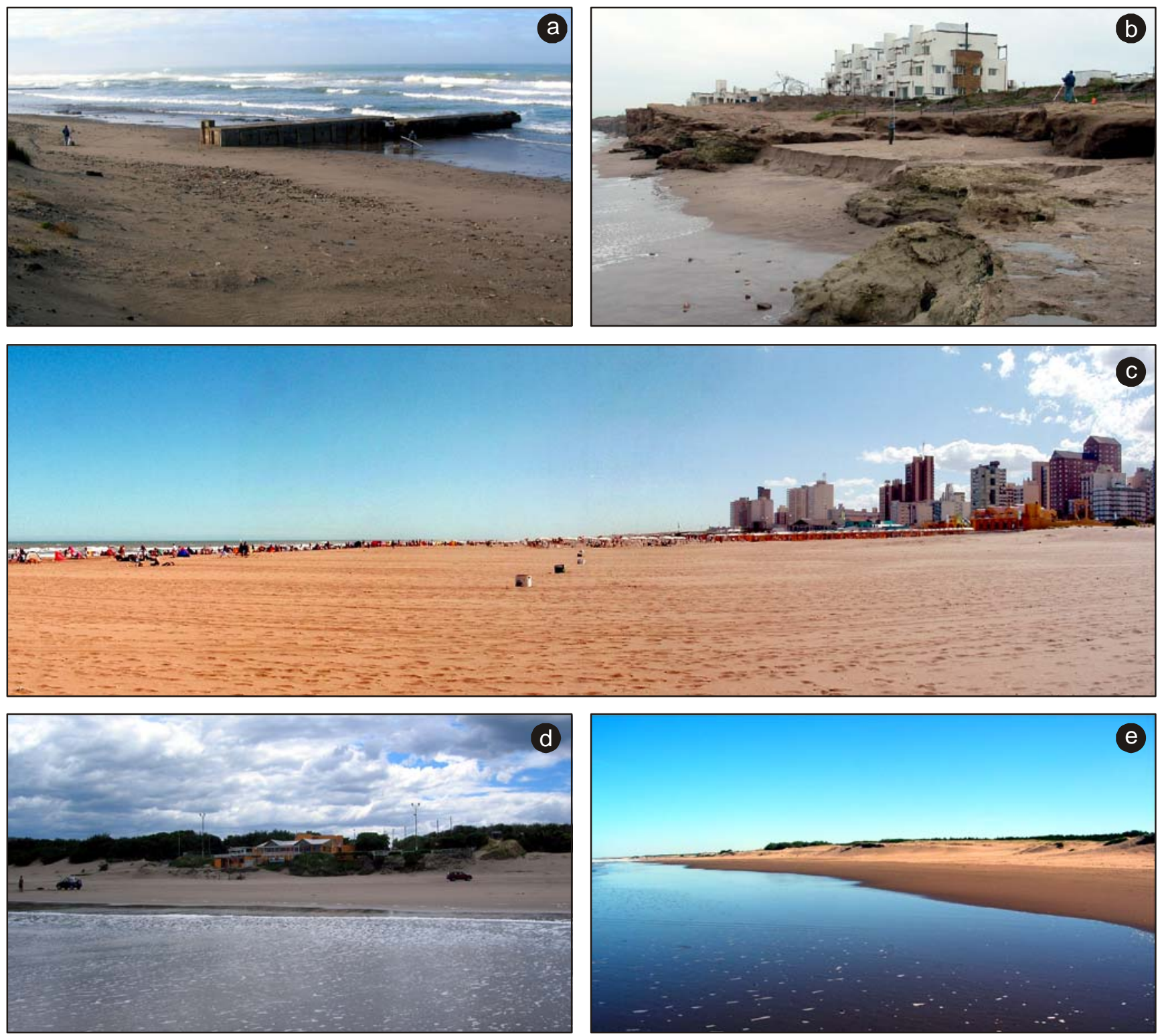

Figure 2. Pictures of the five beaches under study: (a) Costa Bonita and its coastal defenses (26 June 2009), (b) Bahía de los Vientos with post-storm escarpment (21 September 2007), (c) Asilo (28 February 2006), (d) Kabryl (7 December 2007), and (e) Médano Blanco (28 April 2009).

Figura 2. Fotografías de las cinco playas bajo estudio: (a) Costa bonita, donde se aprecian las defensas costeras (26 de junio de 2009 ); (b) Bahía de los Vientos, donde se observa la escarpa de erosión post-temporal de oleaje (21 de septiembre de 2007); (c) Asilo (28 de febrero de 2006); (d) Kabryl (7 de diciembre de 2007); y (e) Médano Blanco (28 de abril de 2009).

operated by the port authority (Consorcio de Gestión de Puerto Quequén). The data were complemented with direct measurements during the surveys. The sensor measurements (20-min measurement interval) were processed by the Wave program for Windows to obtain maximum, mean, and significant wave height; maximum, mean, and significant period; and propagation direction, among other parameters. Standard statistical methods were then used to obtain mean values. Mean spring tide amplitude was taken from the tide tables of the Naval Hydrographic Service (SHN 2009). presenta desarrollo de playa distal. Durante 2009 se efectuaron en ella obras de defensa paralelas a la costa. Asilo (fig. 2c) se ubica frente al sector urbanizado, $1800 \mathrm{~m}$ al oeste de la escollera sur del puerto; es la playa más extensa del partido $(278 \mathrm{~m})$ y posee las pendientes más suaves $(2.6 \%)$. Kabryl y Médano Blanco se localizan frente al parque Miguel Lillo. Kabryl (fig. 2d) posee un ancho medio de $127 \mathrm{~m}$ y una pendiente de playa media (3.8\%); se emplaza al pie de un acantilado inactivo de $4 \mathrm{~m}$ de altura cubierto parcialmente por médanos forestados, y en sus proximidades se encuentra 
A total of 17 seasonal surveys were conducted between February 2006 and December 2009. At the five beaches surveyed (fig. 1), profiles were established perpendicular to the coastline, measured from a fixed point to approximately $0.50 \mathrm{~m}$ below the low water. Elevation was measured every $5 \mathrm{~m}$ using a theodolite (Nikon Nt2a) and a graduated rod. At Costa Bonita, three profiles were taken, with a spacing of $100 \mathrm{~m}$, and referred to the zero elevation of the National Geographic Institute (IGN, Argentina). At the other beaches, one profile was taken and when it was not possible to refer it to an IGN elevation, a relative height was attributed. The beach morphology, foreshore slope, and sediment budget were determined from the analysis of the beach profiles.

The foreshore slope $(P, \%)$ was calculated based on the following equation:

$$
P=\frac{(C 1-C f)}{L} \times 100
$$

where $C 1$ is the berm crest elevation, $C f$ is the elevation of the last point of the profile, and $L$ is the distance between both points.

Sediment volumes were calculated using the conventional method proposed by Fox and Davis (1978), which has been widely used in studies of Buenos Aires beaches (e.g., Bértola 2001, Isla et al. 2009). Sand volume was calculated as the area below the profile, from the fixed point to the base level defined by the last profile elevation, considering a lateral continuity of $5 \mathrm{~m}$ on both sides of the profile. In most cases, beach profiles of different lengths were compared, so the length of the shortest profile was considered in each comparison. The sediment volume for each topographic profile, the seasonal sediment budget, and the total for the period examined were obtained. The topographic profiles of 21 September 2007 and 18 March 2008 showed morphologies and/or volumetric changes that differed from the average beach profiles. As intense storms occurred before these surveys, during which mean significant wave height was 2-3 m for 6 days, these profiles were analyzed to determine changes induced by storm waves.

Grain settling velocity was obtained by the method proposed by Gibbs et al. (1971), using the mean grain size of each beach surveyed. Surface sediment samples were collected from the foreshore during the surveys between September 2007 and December 2009. Depending on particle size, sifting was done using 12 or 18 sieves (ASTM specifications) at 0.5 -phi intervals. Mean grain size and sorting were calculated according to Folk and Ward (1957) using the GRADISTAT program (Blott and Pye 2001).

The classical dimensionless parameters as well as the data obtained from the topographic surveys, sediment samplings, and field measurements were used to classify the beaches according to their morphodynamic state. The predominant wave breaker type was calculated based on $\xi$ : un balneario con bajada de vehículos. Médano Blanco (fig. 2e) posee una pendiente de playa media $(4.0 \%)$ y un ancho medio de $105 \mathrm{~m}$; se localiza al pie de un acantilado con rampa eólica, sobre el cual se emplaza el camino costero que la separa de un campo de médanos vegetados del parque Miguel Lillo.

\section{Trabajo de campo y análisis}

Se obtuvieron datos de oleaje de julio de 2006 a diciembre de 2009 mediante un correntómetro Interocean S4 AWI con sensores de oleaje. El correntómetro se localiza $400 \mathrm{~m}$ al sudoeste de la escollera sur del puerto Quequén (fig. 1) y pertenece al Consorcio de Gestión de Puerto Quequén. Los datos se complementaron con mediciones directas durante las campañas. Las mediciones obtenidas por los sensores (intervalo de medición de $20 \mathrm{~min}$ ) fueron procesadas mediante el programa Wave para Windows para obtener la altura de ola máxima, media y significante; el periodo máximo, promedio y significante; y la dirección de procedencia, entre otros parámetros. Luego, mediante técnicas estadísticas estándar, se obtuvieron los valores medios. La amplitud media de las mareas de sicigia se adquirió de la tabla de mareas del Servicio de Hidrografía Naval (SHN 2009).

Se efectuaron 17 campañas estacionales entre febrero de 2006 y diciembre de 2009. Se levantaron perfiles de playa perpendiculares a la línea de costa en las cinco playas estudiadas (fig. 1), medidos desde un punto fijo hasta aproximadamente $0.50 \mathrm{~m}$ por debajo del nivel de bajamar. Las cotas fueron tomadas cada $5 \mathrm{~m}$ de distancia utilizando un teodolito (Nikon Nt2a) y una mira graduada. En Costa Bonita se realizaron tres perfiles, con un espaciamiento de $100 \mathrm{~m}$, que fueron referidos a la cota topográfica cero del Instituto Geográfico Nacional (IGN, Argentina). En las playas restantes se efectuó un perfil y cuando no fue posible referir el perfil a una cota del IGN, se atribuyó una altura relativa. A partir del análisis de los perfiles de playa, se determinó la morfología de las playas, la pendiente de playa frontal y el balance sedimentario. La pendiente de playa frontal $(P, \%)$ se calculó mediante la siguiente ecuación:

$$
P=\frac{(C 1-C f)}{L} \times 100
$$

donde $C 1$ es la cota de la cresta de la berma, $C f$ es la cota del último punto del perfil y $L$ es la distancia entre ambos puntos.

Los volúmenes de sedimentos se calcularon mediante la técnica convencional propuesta por Fox y Davis (1978), que ha sido ampliamente utilizada en el estudio de las playas bonaerenses (e.g., Bértola 2001, Isla et al. 2009). El volumen de arena se calculó como el área bajo el perfil, desde el punto fijo y hasta el nivel base definido por la última cota del perfil, considerando una continuidad lateral de $5 \mathrm{~m}$ a ambos 


$$
\xi=\frac{\tan \beta}{\sqrt{\left(H_{b} / L_{o}\right)}}
$$

where $\tan \beta$ is the mean foreshore slope, $H_{b}$ is the breaker wave height, and $L_{o}$ is the wave length in deep waters (Masselink and Hughes 2003). $L_{o}$ was calculated as:

$$
L_{o}=\frac{g T^{2}}{2 \pi}
$$

where $T$ is the wave period and $g$ is the acceleration due to gravity.

The following equation was used to obtain $\Omega$ (Wright and Short 1984):

$$
\Omega=\frac{H_{b}}{w_{s} T}
$$

where $w_{s}$ is the grain settling velocity.

The parameter proposed by Masselink and Short (1993) considers $\Omega$ and incorporates the relative tide range (RTR):

$$
\mathrm{RTR}=\frac{\mathrm{MSR}}{H_{b}}
$$

where MSR is the mean spring tide range.

\section{RESULTS}

\section{Wave climate}

Wave height showed a seasonal behavior (fig. 3). Mean daily significant wave height was highest $(1.26 \mathrm{~m})$ in winter (June to August) and lowest $(0.96 \mathrm{~m})$ in summer (December to February). Autumn and spring had the same mean significant wave height $(1.18 \mathrm{~m})$.

Wave direction was ESE to SW (fig. 4), with a predominance of waves from the SSE in all seasons. In summer and autumn, the dominant waves were from the SSE $(32 \%$ and $35 \%$, respectively) and from the $\mathrm{S}$; however, in spring and summer, the predominance of waves from the SSE was more marked $(42 \%)$ and the frequency of waves from the $S$ decreased. In spring and summer, the dominant waves were from the SE, whereas in autumn and winter the dominant waves were from the SSW. This was related to the greater frequency of winds from the $\mathrm{W}$ and SW in autumn and winter and from the E and SE in spring and summer (Merlotto and Piccolo 2009).

Regarding wave height in relation to wave direction (fig. 4), the highest values corresponded to waves from the S and SW in autumn, winter, and summer, and from the SSE in spring. Waves higher than $3 \mathrm{~m}$ had a frequency of $9.3 \%$ in lados del perfil. En la mayoría de los casos se contrastaron perfiles de playa de distinta longitud; por lo tanto, en cada comparación se tomó en cuenta la longitud del perfil más corto. Se obtuvieron los volúmenes sedimentarios de cada perfil, el balance sedimentario estacional y el total para el periodo estudiado. Los levantamientos topográficos del 21 de septiembre de 2007 y del 18 de marzo de 2008 mostraron morfologías y/o cambios volumétricos que destacaron con respecto a los perfiles promedio de las playas. En los días previos a dichas campañas, se registraron intensos temporales durante los cuales la altura de ola significante media diaria fue de 2-3 m durante más de 6 días. Debido a ello, se analizaron estos levantamientos topográficos para abordar el estudio de los cambios producidos en las playas por temporales de oleaje.

La velocidad de caída de grano se obtuvo a partir del método de Gibbs et al. (1971), empleando el tamaño medio de grano de cada playa estudiada. Las muestras superficiales de sedimentos de playa frontal se recolectaron durante las campañas efectuadas entre septiembre de 2007 y diciembre de 2009. De acuerdo con la granulometría del sedimento, se utilizaron 12 o 18 tamices para el tamizado, norma ASTM, cada 0.5 phi de intervalo. El tamaño medio de grano y la selección se calcularon mediante el método propuesto por Folk y Ward (1957) utilizando el programa GRADISTAT (Blott y Pye 2001).

Para clasificar las playas de acuerdo con su estado morfodinámico, se utilizaron los parámetros adimensionales clásicos así como los datos de los levantamientos topográficos, los muestreos de sedimentos y las mediciones de campo. El tipo de rompiente predominante se calculó a partir de $\xi$ :

$$
\xi=\frac{\tan \beta}{\sqrt{\left(H_{b} / L_{o}\right)}}
$$

donde $\tan \beta$ es la pendiente media de la playa frontal, $H_{b}$ es la altura de ola en rompiente y $L_{o}$ es la longitud de onda del oleaje en aguas profundas (Masselink y Hughes 2003). La $L_{o}$ se calculó como:

$$
L_{o}=\frac{g T^{2}}{2 \pi}
$$

donde $T$ es el periodo de ola y $g$ es la aceleración de la gravedad.

El $\Omega$ se obtuvo a partir de la siguiente ecuación (Wright y Short 1984):

$$
\Omega=\frac{H_{b}}{w_{s} T}
$$

donde $w_{s}$ es la velocidad de caída de grano. 
winter, $5.3 \%$ in spring, $4.7 \%$ in autumn, and $2.8 \%$ in summer. Waves with daily mean significant wave height greater than $4.5 \mathrm{~m}$ were recorded in winter and spring (frequencies of $1.6 \%$ and $0.5 \%$, respectively), and waves higher than $6 \mathrm{~m}$ $(0.6 \%)$ were only recorded in winter.

\section{Morphosedimentary variations}

The beaches on the west and east sides of Quequén port (fig. 1) are composed of sediments of different grain sizes. The Necochea beaches (Asilo, Kabryl, and Médano Blanco) are composed of well-sorted fine sands, whereas the Quequén beaches (Bahía de los Vientos and Costa Bonita) are composed of poorly- or moderately-sorted medium to coarse sands (table 1). Costa Bonita is also composed of fine gravel, constituting a mixed sand and gravel beach. Seasonally, the sediments were finer in winter and spring than in autumn and summer, though at Médano Blanco and Kabryl they were finer in summer than in spring.

By studying sediment volumes and their variations, it is possible to determine the state and evolution of beaches and estimate differences and changes in the sediment supply. Between February 2006 and December 2009, sediment loss occurred in the study area for the most part of each year. The beaches had negative sediment budgets in all the seasons except autumn (table 1), when all of them had positive budgets. The highest sediment losses were recorded at Costa Bonita $\left(-108.9 \mathrm{~m}^{3}\right)$, Asilo $\left(-400 \mathrm{~m}^{3}\right)$, and Kabryl $\left(-254.8 \mathrm{~m}^{3}\right)$ (table 1). Though erosion occurred in winter at Bahía de los Vientos $\left(-208.9 \mathrm{~m}^{3}\right)$ and Médano Blanco $\left(-128.2 \mathrm{~m}^{3}\right)$, the greatest decrease in volume occurred in summer at Bahía de los Vientos $\left(-287.3 \mathrm{~m}^{3}\right)$ and in spring at Médano Blanco
El parámetro propuesto por Masselink y Short (1993) considera el $\Omega$ y adiciona el efecto de las mareas con el parámetro amplitud relativa de las mareas (ARM):

$$
\mathrm{ARM}=\frac{\mathrm{AMS}}{H_{b}}
$$

donde AMS es la amplitud media de las mareas de sicigia.

\section{RESUltados}

\section{Clima de oleaje}

La altura de ola presentó un comportamiento estacional (fig. 3). La altura de ola significante media diaria presentó los valores más altos $(1.26 \mathrm{~m})$ en invierno (junio a agosto) y los más bajos $(0.96 \mathrm{~m})$ en verano (diciembre a febrero). El otoño y la primavera presentaron la misma altura de ola significante media $(1.18 \mathrm{~m})$.

La dirección de procedencia del oleaje fue de ESE a SW (fig. 4), con un predominio de las olas provenientes del SSE en todas las estaciones del año. En verano y otoño destacaron, además de las olas del SSE (32\% y 35\%, respectivamente), olas provenientes del S. En cambio, en primavera e invierno el predominio de olas del SSE fue más marcado (42\%) y disminuyó la frecuencia de olas provenientes del S. En primavera y verano destacaron las olas del SE, mientras que en otoño e invierno, las del SSW. Esto se vinculó a la mayor frecuencia de los vientos del W y SW en otoño e invierno y del E y SE en primavera y verano (Merlotto y Piccolo 2009).

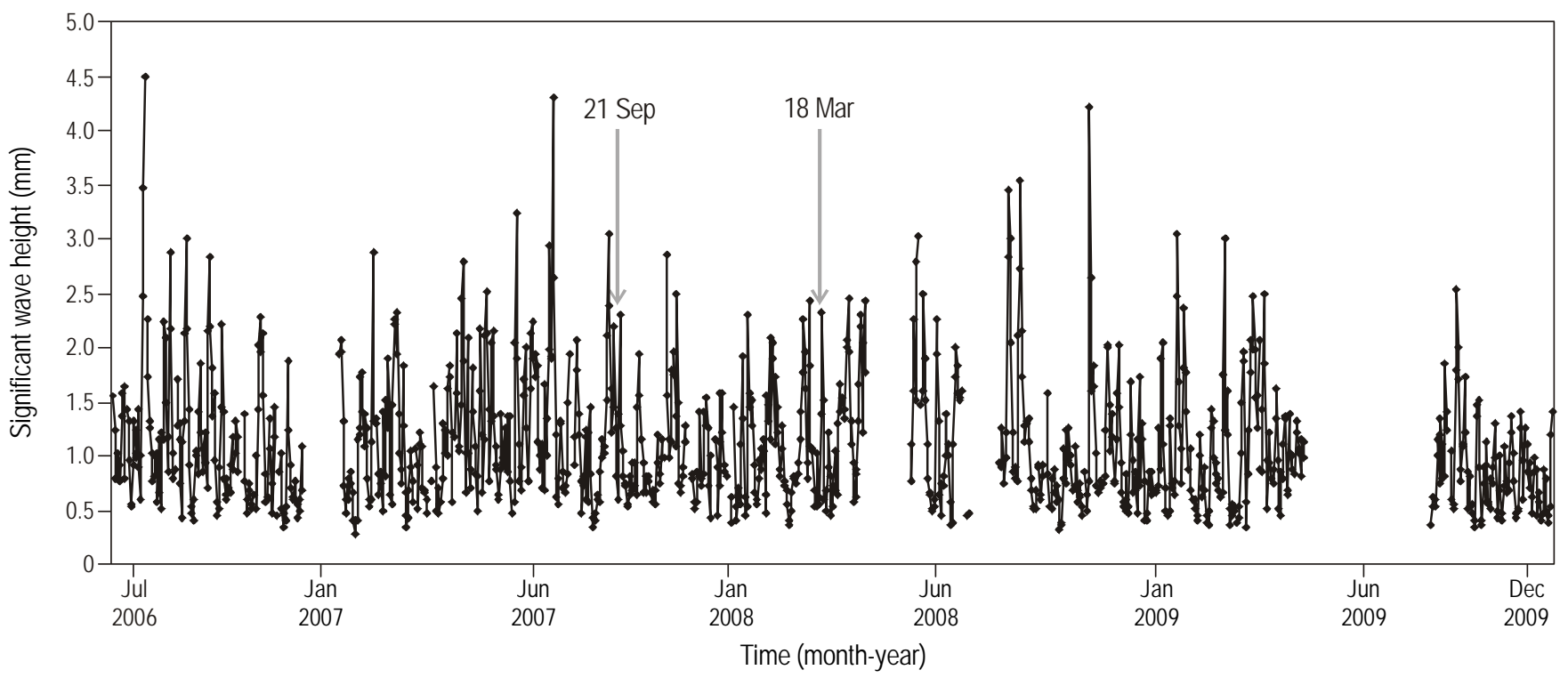

Figure 3. Mean daily significant wave height from July 2006 to December 2009 (based on wave sensor measurements). The dates of the poststorm field surveys are shown with arrows (21 September 2007 and 18 March 2008).

Figura 3. Altura de ola significante media diaria de julio de 2006 a diciembre de 2009 (basado en el sensor de oleaje). Se indican con flechas las fechas de los levantamientos topográficos post-temporales de oleaje (21 de septiembre de 2007 y 18 de marzo de 2008). 

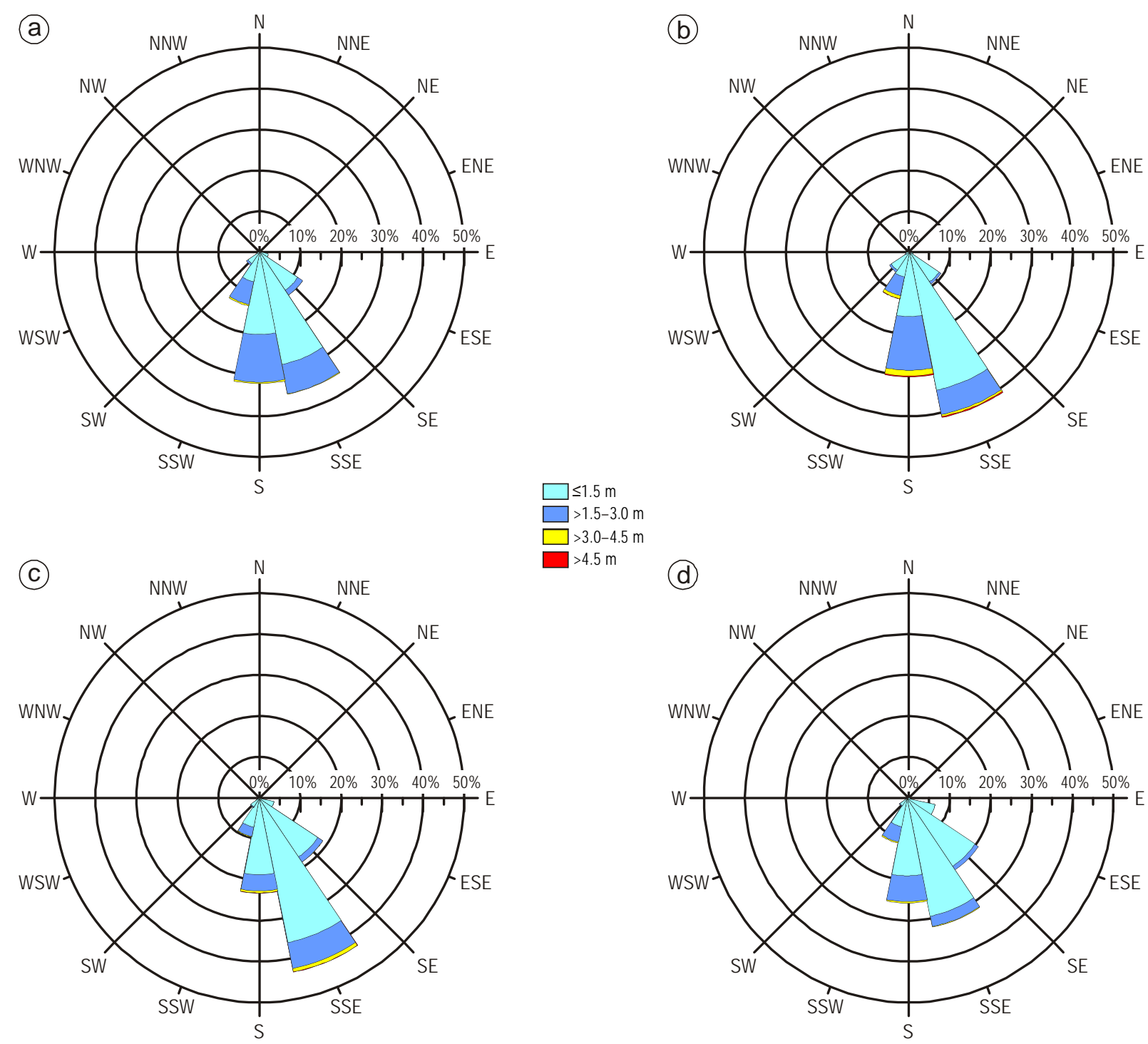

Figure 4. Significant wave direction and wave height (m) frequencies in (a) autumn, (b) winter, (c) spring, and (d) summer from July 2006 to December 2009 (based on wave sensor measurements).

Figura 4. Frecuencia de dirección de ola y altura de ola significante (m) en (a) otoño, (b) invierno, (c) primavera y (d) verano de julio de 2006 a diciembre de 2009 (basado en el sensor de oleaje).

$\left(-146.2 \mathrm{~m}^{3}\right)$. At the Quequén beaches, sand recovery occurred only in autumn (Costa Bonita, $157 \mathrm{~m}^{3}$; Bahía de los Vientos, $377.2 \mathrm{~m}^{3}$ ). At the Necochea beaches, sand recovery occurred in autumn at Médano Blanco; in spring, summer, and autumn at Asilo; and in summer and autumn at Kabryl (table 1). The sediment budget for the whole study period was negative for the two Quequén beaches (Bahía de los Vientos, $-47.5 \mathrm{~m}^{3}$; Costa Bonita, $-24.1 \mathrm{~m}^{3}$ ) and for Médano Blanco $\left(-55.9 \mathrm{~m}^{3}\right)$, but positive for the Necochea beaches closest to the port (Asilo, $53.2 \mathrm{~m}^{3}$; Kabryl, $76.8 \mathrm{~m}^{3}$ ).

The two Quequén beaches had steeper foreshore slopes (fig. 5a-d) than the Necochea beaches (fig. 5e-g). Bahía de los Vientos had the steepest slopes (mean foreshore slope of 7.7\%) and Costa Bonita more moderate slopes (4.6\%)
En cuanto a la altura de ola según su dirección de procedencia (fig. 4), los valores mayores correspondieron a las olas procedentes del S y SW en otoño, invierno y verano, y del SSE en primavera. Las olas con alturas mayores que $3 \mathrm{~m}$ presentaron una frecuencia de $9.3 \%$ en invierno, $5.3 \%$ en primavera, $4.7 \%$ en otoño y $2.8 \%$ en verano. Durante el invierno y la primavera se registraron olas con alturas de ola significante media diaria mayores que $4.5 \mathrm{~m}$ (frecuencias de $1.6 \%$ y $0.5 \%$, respectivamente), y sólo en invierno se registraron olas con alturas mayores que $6 \mathrm{~m}(0.6 \%)$.

\section{Variaciones morfosedimentarias}

Las playas están compuestas por sedimentos de diferente granulometría a ambos lados del puerto Quequén (fig. 1). Las 
Table 1. Seasonal mean grain size, foreshore slope, sediment budgets, Iribarren number ( $\xi$ ), and morphodynamic beach states according to the dimensionless fall velocity $(\Omega)$ (Wright and Short 1984) and the relative tide range (RTR) (Masselink and Short 1993) for the beaches under study.

Tabla 1. Tamaño medio de grano, pendiente de playa frontal, balances sedimentarios, número de Iribarren $(\xi)$ y estados morfodinámicos de acuerdo con al Parámetro adimensional de asentamiento $(\Omega)$ (Wright y Short 1984) y el parámetro de amplitud relativa de mareas (RTR, por sus siglas en inglés) (Masselink y Short 1993) por estación para las playas estudiadas.

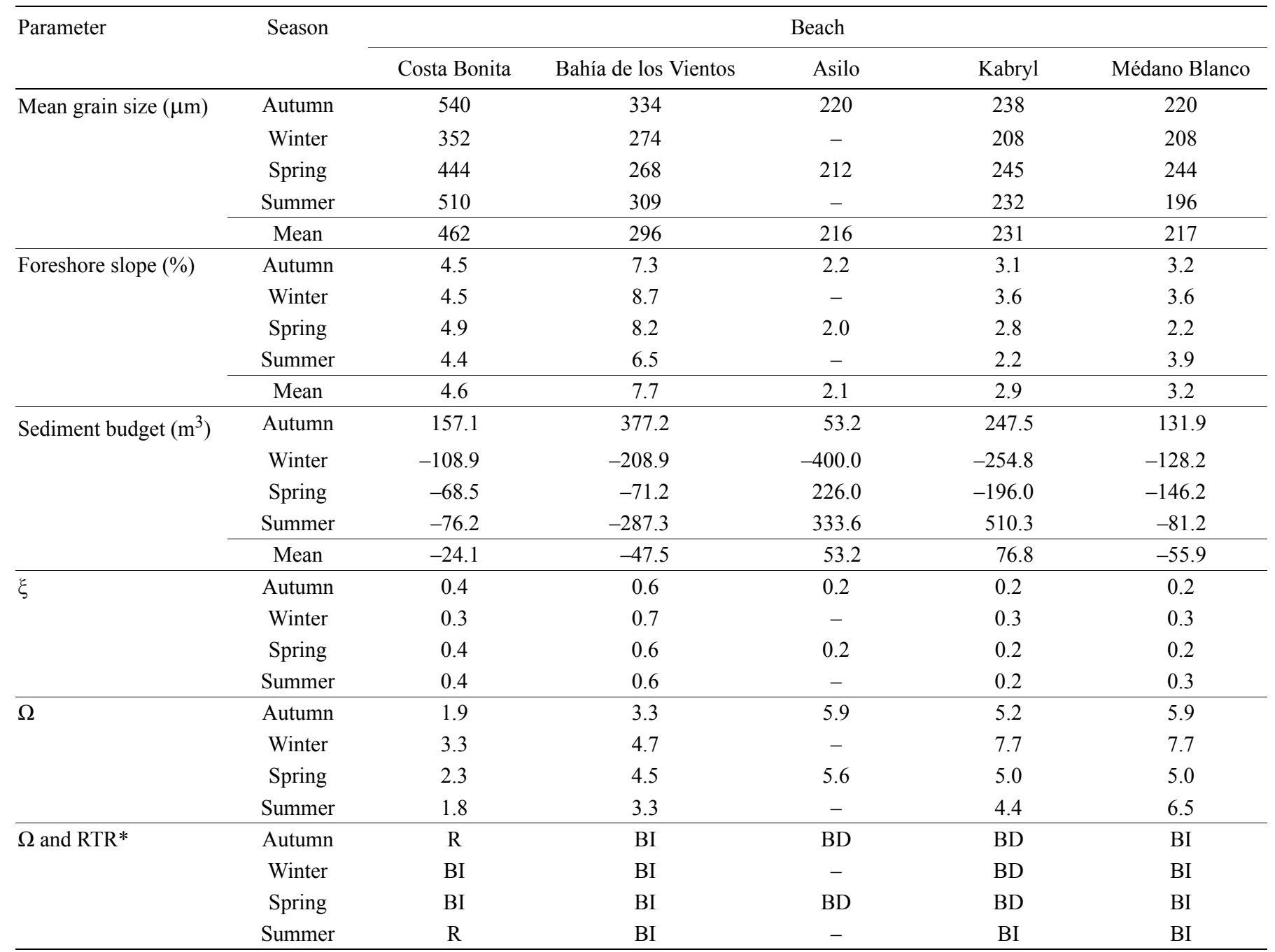

* Beach state: R, reflective; BD, barred dissipative; BI, barred intermediate.

(table 1). Asilo had the gentlest slopes (2.1\%), followed by Kabryl (2.9\%) and Médano Blanco (3.2\%) (table 1).

The topographic surveys of 21 September 2007 and 18 March 2008 were conducted after intense storm waves (fig. 3) and revealed changes at all five beaches. The winter of 2007 and summer of 2008 were periods of intense beach erosion at all the sites, except in summer at Kabryl, where improvements made to the resort's infrastructure modified the beach profile. One of the most evident morphological changes was observed on 21 September 2007 at Bahía de los Vientos, where a 1.35-m-high escarpment (figs. 2b, 5d) and a slope of $10.5 \%$ (from the crest to the end of the profile) were measured after a storm that generated a mean daily significant wave height of $2-3 \mathrm{~m}$ for 7 days prior to the survey playas de Necochea (Asilo, Kabryl y Médano Blanco) están conformadas por arenas finas con buena selección, mientras que las de Quequén (Bahía de los Vientos y Costa Bonita) por arenas medianas a gruesas, pobremente seleccionadas o con moderada selección (tabla 1). Costa Bonita además está conformada por gravas finas, constituyendo una playa mixta de arena y grava. Estacionalmente, durante el invierno y la primavera los sedimentos de las playas fueron más finos que en otoño y verano, aunque en Médano Blanco y Kabryl fueron más finos en verano que en primavera.

El estudio de los volúmenes sedimentarios y sus variaciones permite conocer el estado y la evolución de las playas y estimar posibles diferencias y cambios en las fuentes de alimentación. En el periodo de febrero de 2006 a diciembre 
(fig. 3). Storm waves can also considerably reduce the foreshore slope (fig. 5) due to intensive sediment loss. Such changes were detected after the survey of 18 March 2008 following an 8-day-long event with a mean daily significant wave height of 1.5-2.5 m (fig. 3). At Bahía de los Vientos, for example, the foreshore slope of $4.0 \%$ and the topographic beach level were the lowest recorded during the study period (fig. $5 \mathrm{~d}$ ); $703.1 \mathrm{~m}^{3}$ of sand were lost relative to the previous profile.

In addition to the changes mentioned, sediment movement was observed from the berm toward the sea during the September 2007 and March 2008 surveys, in some cases forming a small bar and trough. These geoforms were more apparent at Costa Bonita (fig. 5a-c) and to a lesser extent at Kabryl and Médano Blanco (fig. 5f-g). The changes were less important at Asilo (fig. 5e) and Médano Blanco (fig. 5g).

\section{Morphodynamic classification}

According to $\xi$, spilling breakers predominated throughout the year at the Necochea beaches. At Quequén, plunging waves predominated all year round, except in winter at Costa Bonita, when spilling breakers predominated. The predominant wave breaker type at the beaches is related to the different foreshore slope values and variations throughout the year. Plunging breakers occurred at the beaches with steeper slopes (Quequén beaches). During the surveys, primarily at the Quequén beaches, spilling breakers were observed after the first plunging breaker or between plunging breakers. Plunging breakers were less frequently observed at Kabryl and Médano Blanco. The predominance of one breaker type or another varied depending on sea conditions on the day of the survey.

The seasonal morphodynamic state of the beaches surveyed was established according to the models proposed by Wright and Short (1984) and Masselink and Short (1993). Based on Wright and Short (1984), the predominant morphodynamic state was intermediate at the Quequén beaches and dissipative at the Necochea beaches (table 1). At Costa Bonita (fig. 5a-c), in autumn, spring, and summer the morphodynamic state was intermediate with low tide terrace, with conditions similar to those of the reflective state; in winter the predominant state was intermediate with bar and rip currents. At Bahía de los Vientos (fig. 5d), the intermediate states predominated (table 1). Towards the west, in autumn and spring the predominant morphodynamic state at Asilo (fig. 5e) was dissipative. Kabryl (fig. 5f) was a dissipative beach in winter and, with conditions similar to those of that state, it became an intermediate beach with longitudinal bar and trough in autumn and spring; in summer, the predominant state was intermediate with rhythmic bars (table 1). Médano Blanco (fig. $5 \mathrm{~g}$ ) was a dissipative beach during most of the year except in spring when it became an intermediate beach with longitudinal bar and trough (table 1).

Based on the parameter proposed by Masselink and Short (1993), the intermediate states immediately before the de 2009, se registró pérdida de sedimentos en el área de estudio durante la mayor parte de cada año. Las playas presentaron saldos sedimentarios negativos en casi todas las estaciones del año a excepción del otoño (tabla 1), cuando todas presentaron saldos positivos. La mayor pérdida de sedimentos fue en inverno en Costa Bonita $\left(-108.9 \mathrm{~m}^{3}\right)$, Asilo $\left(-400 \mathrm{~m}^{3}\right)$ y Kabryl $\left(-254.8 \mathrm{~m}^{3}\right)$ (tabla 1$)$. Aunque el invierno también fue erosivo en Bahía de los Vientos $\left(-208.9 \mathrm{~m}^{3}\right)$ y en Médano Blanco $\left(-128.2 \mathrm{~m}^{3}\right)$, el mayor descenso del volumen ocurrió en verano en Bahía de los Vientos $\left(-287.3 \mathrm{~m}^{3}\right)$ y en primavera en Médano Blanco $\left(-146.2 \mathrm{~m}^{3}\right)$. Los periodos acumulativos estuvieron restringidos al otoño en las playas de Quequén, con volúmenes de 157.1 y $377.2 \mathrm{~m}^{3}$ para Costa Bonita y Bahía de los Vientos, respectivamente. En Necochea, Médano Blanco también mostró recuperación de sedimentos sólo en otoño, mientras que Asilo la mostró en primavera, verano y otoño, y Kabryl en verano y otoño (tabla 1). El balance sedimentario del total del periodo estudiado fue negativo en las playas de Quequén y en Médano Blanco (Necochea). En Quequén, la mayor pérdida de sedimentos se manifestó en Bahía de los Vientos $\left(-47.5 \mathrm{~m}^{3}\right)$ y luego en Costa Bonita $\left(-24.1 \mathrm{~m}^{3}\right)$. Médano Blanco registró una erosión de $-55.9 \mathrm{~m}^{3}$. En cambio, en las playas de Necochea próximas al puerto, el balance sedimentario final fue acumulativo (53.2 $\mathrm{m}^{3}$ en Asilo y $76.8 \mathrm{~m}^{3}$ en Kabryl).

Las pendientes de playa frontal fueron mayores en las dos playas de Quequén (fig. 5a-d) que en las playas de Necochea (fig. 5e-g). Bahía de los Vientos presentó pendientes fuertes (pendiente media de playa frontal de 7.7\%) y Costa Bonita pendientes moderadas (4.6\%) (tabla 1). Asilo presentó las pendientes más suaves $(2.1 \%)$, seguida de Kabryl (2.9\%) y Médano Blanco (3.2\%) (tabla 1).

Luego de los levantamientos topográficos del 21 de septiembre de 2007 y 18 de marzo de 2008, efectuados días posteriores a intensos temporales de oleaje (fig. 3), se observaron cambios notables en las playas estudiadas. El invierno de 2007 y el verano de 2008 fueron periodos de alta erosión en todas las playas, excepto el verano en Kabryl, donde se realizaron obras de mejoramiento de la infraestructura balnearia que modificaron el perfil de playa. Una de las morfologías más notables se observó en Bahía de los Vientos el 21 de septiembre de 2007. Luego del temporal que generó una altura de ola significante media diaria de 2-3 m durante 7 días previos al levantamiento (fig. 3), se registró una escarpa de erosión de $1.35 \mathrm{~m}$ de altura (figs. $2 \mathrm{~b}, 5 \mathrm{~d}$ ) y una pendiente de $10.5 \%$ desde la cresta hasta el final del perfil. Se observó que los temporales de oleaje también pueden reducir la pendiente frontal notablemente (fig. 5) debido a una intensa pérdida de sedimentos. Dichos cambios fueron registrados luego del levantamiento topográfico del 18 de marzo de 2008, posterior a un evento de 8 días de duración con alturas significantes medias diarias de ola de 1.5 a $2.5 \mathrm{~m}$ (fig. 3). En Bahía de los Vientos, por ejemplo, la pendiente frontal fue de $4.0 \%$ y el nivel topográfico de playa fue el menor 

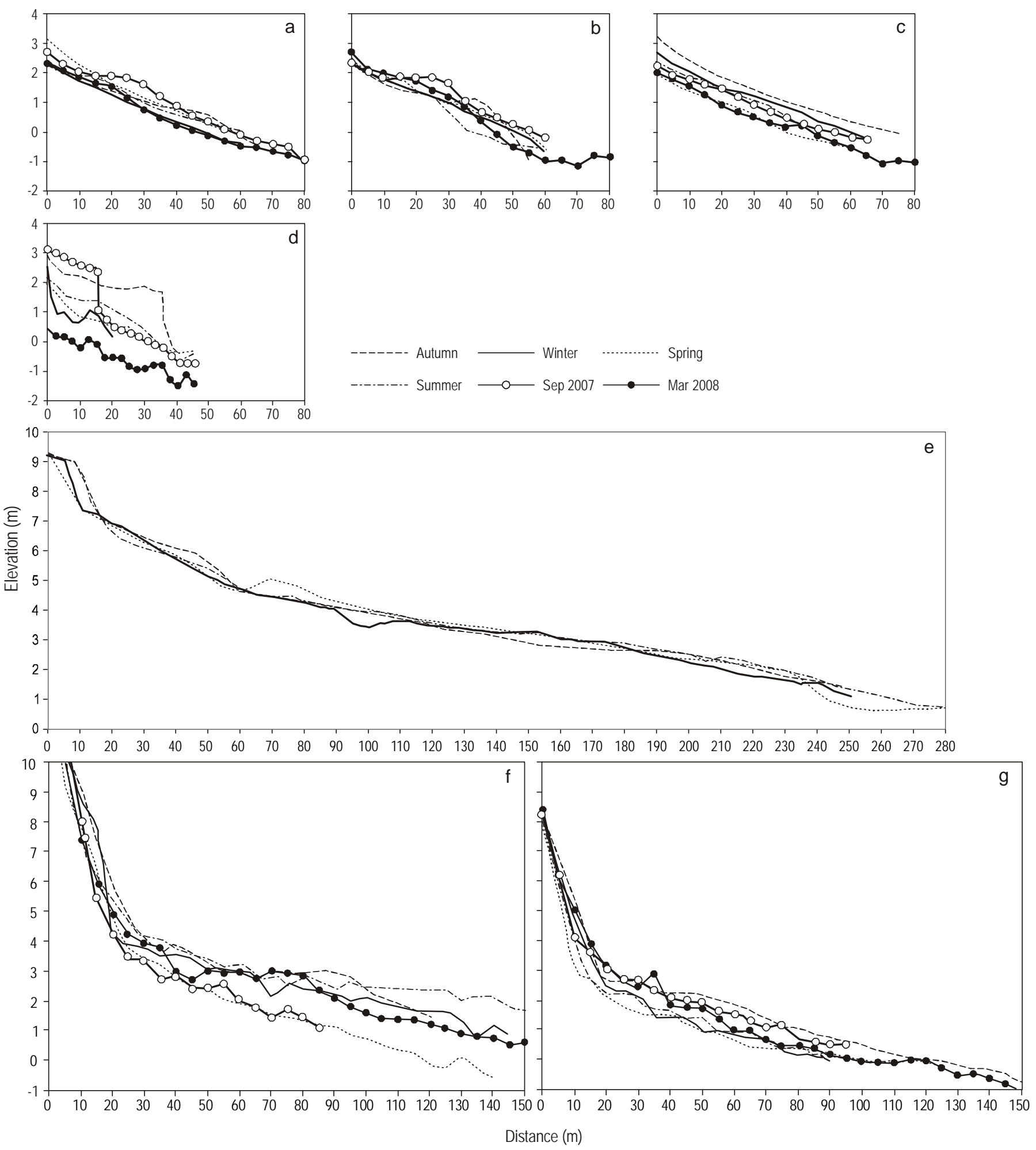

Figure 5. Examples of seasonal and post-storm beach profiles for (a) northern Costa Bonita, (b) central Costa Bonita, (c) southern Costa Bonita, (d) Bahía de los Vientos, (e) Asilo, (f) Kabryl, and (g) Médano Blanco.

Figura 5. Ejemplos de perfiles de playa estacionales y post-tormenta para (a) la parte norte de Costa Bonita, (b) la parte central de Costa Bonita, (c) la parte sur de Costa Bonita, (d) Bahía de los Vientos, (e) Asilo, (f) Kabryl y (g) Médano Blanco. 
reflective and dissipative states, obtained according to Wright and Short (1984), were observed to become fully reflective or dissipative. Hence, Costa Bonita was a reflective beach in autumn and summer and a barred intermediate beach in winter and spring. Bahía de los Vientos was a barred intermediate beach throughout the year (table 1). The Necochea beaches were barred dissipative except for Kabryl in summer, when it was a barred intermediate beach (table 1). The RTR obtained for the study area was 1.01 and 1.34 for winter and summer, respectively, and 1.09 for autumn and spring; therefore, the effect of tidal range was not significant.

\section{DISCUSSION}

The predominant morphodynamic states and sediment variations of the beaches surveyed on both sides of Quequén port differed. At Costa Bonita the predominant morphodynamic state was low tide terrace intermediate, based on Wright and Short (1984), and reflective, based on Masselink and Short (1993). The reflective state develops at beaches composed of coarse to medium sand and protected by groins, such as Costa Bonita. This morphodynamic state was observed at beaches with straight groins in the city of Mar del Plata (Bértola 2006). The dissipative or almost dissipative Necochea beaches characterized by spilling breakers had fine sands, gentle slopes, and wide surf zones. These characteristics have also been observed at dissipative beaches in southeastern Australia and southern Africa (Short 1996). The only other beaches in Buenos Aires Province that present this morphodynamic state are the extensive beaches at Punta Mogotes and the artificially nourished beaches of Mar del Plata (Bértola 2006). Intermediate states occur at beaches with fine to medium sand and plunging and spilling breakers, such as Bahía de los Vientos. These types of beaches are abundant in the eastern part of Buenos Aires Province, to the south of Punta Mogotes and in Miramar (Bértola 2006).

Regarding the seasonal evolution of the morphodynamic states, in winter all the beaches became more dissipative, whereas in summer and autumn they were more more reflective (except Médano Blanco, which was reflective in spring). These results coincide with the morphodynamic behavior described by Masselink and Hughes (2003) and documented for Mexican beaches (Lizárraga-Arciniega et al. 2007). An increase in wave height during winter $(1.26 \mathrm{~m})$ favors offshore sediment transport and the beach switches to a dissipative state. Conversely, a decrease in wave height during summer $(0.96 \mathrm{~m})$ favors onshore sediment transport, producing a more reflective state (Masselink and Hughes 2003). The storm waves prior to the March 2008 topographic survey caused the beaches to change to a dissipative state (fig. 5).

The response of the beaches surveyed to storm waves can be linked to their predominant morphodynamic state. According to Qi et al. (2010), barred beaches present the most complex behavior and can suffer erosion of the berm and seaward migration of the littoral bar. The post-storm registrado en el periodo estudiado (fig. 5d). Se perdieron $703.1 \mathrm{~m}^{3}$ de arena con respecto al perfil previo.

Además de los cambios señalados, en los levantamientos de septiembre de 2007 y marzo de 2008 se observaron movimientos de sedimentos desde la berma hacia el mar, en algunos casos con la formación de una pequeña barra y un canal. Estas geoformas fueron evidentes principalmente en Costa Bonita (fig. 5a-c) y en menor medida en Kabryl y Médano Blanco (fig. 5f-g). Los cambios menos importantes se manifestaron en Asilo (fig. 5e) y Médano Blanco (fig. 5g).

\section{Clasificación morfodinámica}

De acuerdo con $\xi$, las olas en derrame predominaron durante todo el año en las playas de Necochea. En Quequén predominaron las olas en voluta durante todo el año, excepto durante el invierno, en Costa Bonita, cuando prevalecieron las olas con rompiente en derrame. El predominio del tipo de rompiente en las diferentes playas se debe fundamentalmente a los distintos valores de pendiente de playa frontal y a sus variaciones a lo largo del año. La rompiente en voluta se produjo en playas con mayores pendientes (playas de Quequén). Durante las campañas se observaron, principalmente en las playas de Quequén, olas con rompiente en derrame que se produjeron luego de la primera rotura en voluta o entre roturas en voluta. En cambio, se observaron olas con rompiente en voluta con menor frecuencia en Kabryl y Médano Blanco. El predominio de un tipo u otro de rompiente fue variable según el estado del mar en el día de las campañas.

El estado morfodinámico estacional de las playas estudiadas se estableció de acuerdo con los modelos de Wright y Short (1984) y Masselink y Short (1993). Según el modelo de Wright y Short (1984), predominó el estado morfodinámico intermedio en Quequén y el estado disipativo en Necochea (tabla 1). En Costa Bonita (fig. 5a-c), en otoño, primavera y verano se presentó un estado intermedio con terraza en marea baja, el cual involucra condiciones similares a las del estado reflectivo; en invierno el estado predominante fue intermedio con la formación de barra y corriente de retorno. En Bahía de los Vientos (fig. 5d) predominaron los estados intermedios (tabla 1). Hacia el oeste, en Asilo (fig. 5e) predominó el estado morfodinámico disipativo durante el otoño y la primavera. Kabryl (fig. 5f) fue una playa disipativa en invierno y, con condiciones semejantes a las de dicho estado, se tornó intermedia con canal y barra longitudinales en otoño y primavera; en verano, predominó el estado intermedio con barras rítmicas (tabla 1). Médano Blanco (fig. $5 \mathrm{~g}$ ) fue una playa disipativa durante gran parte del año a excepción de la primavera, cuando se tornó en una playa intermedia con canal y barra longitudinales (tabla 1).

De acuerdo con el parámetro propuesto por Masselink y Short (1993), se observó que los estados intermedios inmediatamente previos a los estados reflectivo y disipativo, que resultaron de la aplicación del modelo de Wright y Short (1984), se tornaron netamente reflectivos o disipativos. Por lo 
profiles showed an abrupt escarpment and loss of beach elevation at Bahía de los Vientos (fig. 5d), and this beach was the most sensitive to changes in wave energy. Costa Bonita (fig. 5a-c) showed sediment transport from the berm towards the sea, and erosion in the upper part of the beach and accumulation in the lower part. This response is typical of low tide terrace intermediate beaches (Qi et al. 2010). Kabryl showed changes, though not as important as those of the Quequén beaches, whereas Asilo and Médano Blanco had a more stable behavior and weaker response to storm waves, which is characteristic of dissipative beaches (fig. 5e, g) (Qi et al. 2010).

The sediment budgets for the study period (February 2006 to December 2009) revealed an erosive tendency at the two Quequén beaches and the Necochea beach farthest from the port (Médano Blanco), and an accumulative tendency at Asilo and Kabryl. The beach seasonal cycles showed erosion in winter and spring, and accumulation in autumn and summer, concurring with the predominant morphodynamic states. Larson and Kraus (1994) reported that North Carolina beaches had a similar behavior in spring and autumn, with transitional morphodynamic states between the predominant summer and winter cycles. This behavior was observed only at Kabryl. The Quequén beaches, mainly Bahía de los Vientos, showed the greatest changes in beach profile. Anfuso et al. (2006) found that beach profiles taken close to human-made structures showed greater variability. Hill et al. (2004) also observed a differential behavior of beach profiles measured at sites that were located in close proximity to one another but had different degrees of urbanization. The location of the Quequén beaches is unfavorable in relation to the port's breakwaters and the presence of urban centers. As the cities expanded over the dune fields, the beach-dune interaction was modified and beach sediment supply decreased (Merlotto et al. 2012). Because of the direction of the predominant littoral drift (SW-NE) and winds (N-NW) throughout the year, the Quequén beaches were the most affected by the decrease in sediment supply. The influence of these factors is evinced by the positive sediment budgets at the two Necochea beaches closest to the port and the negative budgets at the Quequén beaches.

The findings of this study contribute to understanding the area under study and have been used to develop measures for the prevention, mitigation, and monitoring of coastal erosion by the aforementioned coastal management program. The beaches to the west of Quequén port differed from those to the east. The Necochea beaches were dissipative, whereas the Quequén beaches, located down-drift, presented intermediate and reflective states. Accretion occurred in autumn and, to a lesser extent, in summer. The Quequén beach profiles showed greater variability and more pronounced changes induced by storm waves; however, given the observations on the effect of storms, future studies should consider beach response and recovery, as well as the storm characteristics. Such studies are important in highly-urbanized areas where tanto, Costa Bonita presentó un estado reflectivo en otoño y verano e intermedio con barra en invierno y primavera, y Bahía de los Vientos presentó un estado intermedio con barra durante todo el año (tabla 1). Las playas de Necochea fueron disipativas con barras a excepción de Kabryl en verano, que manifiestó un estado intermedio con barra (tabla 1). La ARM obtenida para el área de estudio fue 1.01 y 1.34 para invierno y verano, respectivamente, y 1.09 para otoño y primavera; por lo tanto, el efecto de las mareas fue poco significativo.

\section{Discusión}

Las playas estudiadas presentaron diferencias en los estados morfodinámicos predominantes y en las variaciones sedimentarias a ambos lados del puerto Quequén. El estado morfodinámico predominante en Costa Bonita fue intermedio con terraza en marea baja, de acuerdo con la clasificación de Wright y Short (1984), y sería reflectivo según la propuesta de Masselink y Short (1993). El estado reflectivo se genera en playas compuestas por arena gruesa a mediana y protegidas por espigones, como Costa Bonita. Este estado morfodinámico fue observado en playas con espigones rectos de la ciudad de Mar del Plata (Bértola 2006). Las playas de Necochea con estado morfodinámico disipativo o próximas a dicho estado durante gran parte del año y con una rompiente predominante en derrame presentaron granulometrías finas, pendientes suaves y zonas de rompiente amplias. Estas características también fueron observadas en playas disipativas del sudeste de Australia y del sur de África (Short 1996). Las playas disipativas son escasas en la provincia de Buenos Aires, sólo las de gran extensión en punta Mogotes y las que han sido alimentadas artificialmente en la ciudad de Mar del Plata presentan dicho estado morfodinámico (Bértola 2006). Los estados intermedios son propios de playas de arena fina a mediana con rompientes en voluta y derrame, como Bahía de los Vientos. Este tipo de playas son las más abundantes en el este bonaerense, al sur de punta Mogotes y en Miramar (Bértola 2006).

En cuanto a la evolución del estado morfodinámico de las playas a lo largo del año, en invierno todas las playas se aproximaron a un estado más disipativo, mientras que en verano y otoño presentaron un estado más reflectivo (excepto Médano Blanco, donde el estado más reflectivo se observó en primavera). Estos resultados se ajustan al comportamiento morfodinámico descrito por Masselink y Hughes (2003) y observado en playas mexicanas (Lizárraga-Arciniega et al. 2007). El incremento en la altura de ola en invierno $(1.26 \mathrm{~m})$ favorece un transporte de sedimentos mar adentro, produciendo que la playa se vuelva hacia el estado disipativo; por el contrario, un descenso en la altura del oleaje en verano $(0.96 \mathrm{~m})$ ocasiona un predominio de transporte de sedimentos hacia la playa, generando un estado más reflectivo (Masselink y Hughes 2003). El temporal de oleaje previo al levantamiento topográfico de marzo de 2008 ocasionó que las playas evolucionen a un estado disipativo (fig. 5). 
the beach sediment sources have been modified, since a decline in sediment supply hinders beach recovery after intense storms (Loureiro et al. 2009). Moreover, areas with different tendencies (erosive and accumulative) have been distinguished, and appropriate measures can thus be taken in accordance with the specific needs of each sector. The proper functioning of the coastal management plan and reduction of the erosive phenomenon depends on this.

A convenient measure that should be adopted to prevent and mitigate coastal erosion is to avoid the excessive forestation of coastal dunes because when wind transport is interrupted, the exchange of sand between dunes and beach is affected. Moreover, future fixed coastal structures should be planned and designed considering the littoral drift and not interrupt it. In fact, their use should be discarded and beach regeneration works undertaken instead. It is also necessary to respect the beach profile and avoid levelling and destroying the berm and cleaning with machinery, since the natural geoforms of a beach constitute its defense and maintain its dynamic equilibrium. Finally, beach evolution should be systematically monitored and a plan should be implemented to restore the coastal area. These suggestions will help to prevent sediment loss and allow sediment transport from the west to the east of the study area, where the most affected sites are located. They will also permit the long-term sustainable use of the beaches in an area where tourism has great economic potential.

\section{ACKNOWLEDGMENTS}

We thank the municipality of Necochea (Martín Sarasíbar and Gabriel Molina) and Consorcio de Gestión de Puerto Quequén) for the data provided. We also thank the anonymous reviewers for their valuable comments that considerably improved the manuscript.

English translation by Christine Harris.

\section{REFERENCES}

Anfuso G, Gracia FJ, Martínez JA, del-Río L, Andrés J, Sánchez F, López-Aguayo F. 1999. Modelización del comportamiento morfodinámico de las playas mediante el estudio de la profundización de removilización. Estud. Geol. 55: 119-125. http://dx.doi.org/10.3989/egeol.99553-4

Anfuso G, Bello E, Benavente J, Nachite D, Macias A. 2006. Características morfológicas y variabilidad volumétrica de las playas del litoral entre Ceuta y Cabo Negro (Marruecos). Cienc. Mar. 32: 579-588.

Benavente J, del-Río L, Anfuso G, Gracia FJ, Reyes JL. 2002. Utility of morphodynamic characterization in the prediction of beach damage by storms. J. Coast. Res. SI(36): 56-64.

Benedet L, Finkl CW, Campbell T, Klein A. 2004. Predicting the effect of beach nourishment and cross-shore sediment variation on beach morphodynamic assessment. Coast. Eng. 51: 839-861. http://dx.doi.org/10.1016/j.coastaleng.2004.07.012

Bértola GR. 2001. 21 years of morphological modifications in an urbanized beach (Playa Grande, Mar del Plata, Argentina). Thalassas 17: 21-36.
La respuesta de las playas del área de estudio a los temporales de oleaje puede vincularse al estado morfodinámico predominante en ellas. De acuerdo con Qi et al. (2010), las playas con barras muestran el comportamiento más complejo y pueden sufrir erosión de la berma y migración de la barra litoral hacia mar adentro. Luego de los levantamientos topográficos post-temporales, se observó una escarpa abrupta y un descenso importante del nivel de playa en Bahía de los Vientos (fig. 5d), y esta playa resultó ser la más sensible a los cambios de la energía del oleaje. Costa Bonita (fig. 5a-c) presentó movimientos de sedimentos desde la berma hacia el mar, con erosión en la parte alta de la playa y acumulación en la parte baja. Esta respuesta es típica de playas intermedias con terraza en marea baja (Qi et al. 2010). En Necochea, Kabryl manifestó cambios, aunque menos significativos que los de las playas de Quequén, mientras que Asilo y Médano Blanco presentaron un comportamiento más estable con una respuesta más débil a las tormentas de oleaje, característico de las playas disipativas (fig. 5e, g) (Qi et al. 2010).

Los balances sedimentarios del periodo estudiado (febrero de 2006 a diciembre de 2009) mostraron una tendencia erosiva en las dos playas de Quequén y en la playa de Necochea más alejada del puerto (Médano Blanco) y una tendencia acumulativa en las playas cercanas al puerto (Asilo y Kabryl). Los ciclos estacionales en las playas del área de estudio fueron erosivos en invierno y primavera, y acumulativos en otoño y verano. Éstos concuerdan con los estados morfodinámicos predominantes. Larson y Kraus (1994) hallaron que las playas de Carolina del Norte se comportaron en forma similar durante la primavera y el otoño, con estados morfodinámicos transicionales entre los estados predominantes de verano e invierno. Este comportamiento fue observado solamente en Kabryl. Los mayores cambios en el perfil de playa los manifestaron las playas de Quequén, principalmente Bahía de los Vientos. Anfuso et al. (2006) encontraron que los perfiles de playa con mayor variabilidad fueron los próximos a estructuras antrópicas. Un comportamiento diferencial entre perfiles de playa próximos entre sí pero con diferente grado de urbanización fue observado también por Hill et al. (2004). Las playas de Quequén se encuentran en una posición desfavorable con respecto a las escolleras del puerto y a la presencia de los centros urbanos. El crecimiento de las ciudades se efectuó sobre los campos de médanos, modificándose la interacción playa-médano y reduciéndose los aportes de arena hacia las playas (Merlotto et al. 2012). Debido a la dirección predominante de la deriva litoral (SW$\mathrm{NE}$ ) y de los vientos (N-NW) a lo largo del año, las playas más perjudicadas por el descenso de los aportes de sedimentos fueron las de Quequén. La influencia de estos factores se evidencia en los balances sedimentarios positivos en las dos playas de Necochea más cercanas al puerto Quequén y en los balances sedimentarios negativos en las playas de Quequén.

Los resultados de este trabajo constituyen un aporte sustancial al conocimiento del ambiente estudiado y han sido utilizados en el plan de manejo costero integral ya 
Bértola GR. 2006. Morfodinámica de playas del sudeste de la provincia de Buenos Aires (1983 a 2004). Lat. Am. J. Sedimentol. Basin Anal. 13: 31-57.

Blott SJ, Pye K. 2001. GRADISTAT: A grain size distribution and statistics package for the analysis of unconsolidated sediments. Earth Surf. Process. Landforms 26: 1237-1248. http://dx.doi.org/10.1002/esp.261

Boruff BJ, Emrich C, Cutter SL. 2005. Erosion hazard vulnerability of US coastal counties. J. Coast. Res. 21: 932-942. http://dx.doi.org/10.2112/04-0172.1

Fiore MME, D’Onofrio EE, Pousa JL, Schnack EJ, Bértola GR. 2009. Storm surges and coastal impacts at Mar del Plata, Argentina. Cont. Shelf Res. 29: 1643-1649. http://dx.doi.org/10.1016/j.csr.2009.05.004

Folk RL, Ward W. 1957. Brazos River bar: A study in the significance of grain size parameters. J. Sediment. Petrol. 27: 3-26.

Fox W, Davis R Jr. 1978. Seasonal variation in beach erosion and sedimentation on the Oregon coast. Geol. Soc. Am. Bull. 89: $1541-1549$.

Gibbs RJ, Mathews MD, Link DA. 1971. The relationship between sphere size and settling velocity. J. Sediment. Petrol. 41: 7-18.

Gómez-Pujol L, Orfila A, Cañellas B, Alvarez-Ellacuria A, Méndez FJ, Medina R, Tintoré J. 2007. Morphodynamic classification of sandy beaches in low energetic marine environment. Mar. Geol. 242: 235-246.

http://dx.doi.org/10.1016/j.margeo.2007.03.008

Hill HW, Kelley JT, Belknap DF, Dickson SM. 2004. The effects of storms and storm-generated currents on sand beaches in southern Maine, USA. Mar. Geol. 210: 149-168. http://dx.doi.org/10.1016/j.margeo.2004.05.008

Isla FI, Farenga MO, Cortizo LC, Bértola GR, Serra SB. 1997. Dinámica morfosedimentaria de playas de arena y grava de la Barrera Austral: Mar del Sud, Arenas Verdes y Costa Bonita. Rev. Asoc. Argent. Sedimentol. 4: 15-24.

Isla FI, Bértola GR, Schnack EJ. 2001. Morfodinámica de playas meso y macromareales de Buenos Aires, Río Negro y Chubut. Rev. Asoc. Argent. Sedimentol. 8: 51-60.

Isla FI, Iantanos N, Estrada E. 2002. Playas reflectivas y disipativas macromareales del Golfo San Jorge, Chubut. Rev. Asoc. Argent. Sedimentol. 9: 155-164.

Isla F, Bértola G, Merlotto A, Ferrante A, Cortizo LC. 2009. Requerimientos y disponibilidad de arenas para la defensa de las playas de Necochea y Lobería. Rev. Asoc. Geol. Argent. 65: 446-456.

Kokot RR, Codignotto JO, Elissondo M. 2004. Vulnerabilidad al ascenso del nivel del mar en la costa de la provincia de Río Negro. Rev. Asoc. Geol. Argent. 59: 477-487.

Komar PD. 2010. Shoreline evolution and management of Hawke's Bay, New Zealand: Tectonics, coastal processes, and human impacts. J. Coast. Res. 26: 143-156. http://dx.doi.org/10.2112/08-1079.1

Larson M, Kraus NC. 1994. Temporal and spatial scales of beach profile change, Duck, North Carolina. Mar. Geol. 117: 75-94. http://dx.doi.org/10.1016/0025-3227(94)90007-8

Lizárraga-Arciniega R, Martínez-Díaz de León A, DelgadoGonzález O, Torres CR, Galindo-Bect LA. 2007. Alternation of beach erosion/accreetion cycles related to wave action off Rosarito, Baja California, Mexico. Cienc. Mar. 33: 259-269.

Loureiro C, Ferreira Ó, Cooper JAG. 2009. Contrasting morphological behaviour at embayed beaches in southern Portugal. J. Coast. Res. SI(56): 83-87.

Masselink G, Short AD. 1993. The effect of tide range on beach morphodynamics and morphology: A conceptual beach model. J. Coast. Res. 9: 785-800. mencionado para la elaboración de medidas de prevención, mitigación y monitoreo de la erosión costera. Las playas estudiadas presentaron diferencias a ambos lados del puerto Quequén. Las playas de Necochea fueron disipativas, mientras que las de Quequén, localizadas deriva abajo del puerto, presentaron estados intermedios y reflectivos. Los periodos acrecionales se limitaron al otoño y en menor medida al verano. La mayor variabilidad del perfil se observó en las playas de Quequén, en las cuales los cambios producidos por los temporales de oleaje fueron más intensos. Sin embargo, dadas las observaciones de esta primera aproximación al estudio del efecto de los temporales de oleaje, es necesario que en estudios futuros se considere la respuesta de las playas y su recuperación, así como las características de las tormentas. Dicho estudio resulta fundamental en un área intensamente urbanizada y en la cual las fuentes de alimentación de las playas han sido modificadas, ya que el descenso en la provisión de sedimentos dificulta la recuperación de las mismas luego de temporales severos (Loureiro et al. 2009). Además, se han podido discriminar áreas con diferentes tendencias (áreas erosivas y acumulativas) lo cual permite desarrollar medidas de actuación acordes a las necesidades de cada sector. De ello depende la reducción del fenómeno erosivo y el adecuado funcionamiento del plan de manejo costero.

Entre las medidas más convenientes a adoptar para la prevención y mitigación de la erosión costera, se sugiere evitar la forestación excesiva de los médanos costeros porque, al interrumpir el transporte eólico, perjudica el intercambio de arena entre la playa y los médanos. En este sentido, se recomienda evitar interrumpir la deriva litoral durante el planeamiento y diseño de futuras defensas costeras fijas. Asimismo, éstas deberían evitarse y sería conveniente realizar obras como la regeneración de playas o sistemas de traspaso (bypass). Además, es necesario respetar el perfil de playa evitando la nivelación y destrucción de la berma y la limpieza con maquinarias, ya que las geoformas naturales de la playa constituyen la defensa natural de la misma y mantienen su equilibrio dinámico. Por último, debería efectuarse un seguimiento de la evolución de las playas mediante un programa de monitoreo sistemático y control, e implementarse un plan de recuperación del área costera. Las sugerencias mencionadas, entre otras, serán de utilidad para prevenir la pérdida de sedimentos y favorecer su transporte desde el oeste hacia el este del área de estudio, donde se localizan las áreas más perjudicadas. Asimismo, permitirán un uso sostenible a largo plazo de las playas, en un área donde el turismo presenta un gran potencial económico.

\section{AgRADECIMIENTOS}

Los autores agradecen a la Municipalidad de Necochea (Martín Sarasíbar y Gabriel Molina) y al Consorcio de Gestión de Puerto Quequén los datos proporcionados. Agradecen además a los revisores anónimos las valiosas sugerencias que mejoraron sustancialmente el manuscrito. 
Masselink G, Hughes MG. 2003. Introduction to Coastal Processes and Geomorphology. Oxford Univ. Press, New York, 354 pp.

Merlotto A, Bértola GR. 2008. Evolución urbana y su influencia en la erosión costera en el balneario Parque Mar Chiquita, Argentina. Pap. Geogr. 47-48: 143-158.

Merlotto A, Bértola GR. 2009. Coastline evolution at Balneario Parque Mar Chiquita, Argentina. Cienc. Mar. 35: 271-286.

Merlotto A, Piccolo MC. 2009. Tendencia climática de NecocheaQuequén (1956-2006), Argentina. Invest. Geogr. 50: 143-167.

Merlotto A, Piccolo MC, Bértola GR. 2012. Crecimiento urbano y cambios del uso/cobertura del suelo en las ciudades de Necochea y Quequén, Buenos Aires, Argentina. Rev. Geogr. Norte Gd. 53: 159-176.

http://dx.doi.org/10.4067/S0718-34022012000300010

Perillo GME, Pérez DE, Piccolo MC, Palma ED, Cuadrado DG. 2005. Geomorphologic and physical characteristics of a human impacted estuary: Quequén Grande River Estuary, Argentina. Estuar. Coast. Shelf Sci. 62: 301-312. http://dx.doi.org/10.1016/j.ecss.2004.09.018
Qi H, Cai F, Lei G, Cao H, Shi F. 2010. The response of three main beach types to tropical storms in South China. Mar. Geol. 275: 244-254. http://dx.doi.org/10.1016/j.margeo.2010.06.005

Regnauld H, Pirazzoli PA, Morvan G, Ruz M. 2004. Impacts of storms and evolution of the coastline in western France. Mar. Geol. 210: 325-337. http://dx.doi.org/10.1016/j.margeo.2004.05.014

SHN. 2009. Tablas de Marea. Servicio de Hidrografía Naval. Armada Argentina, Buenos Aires, 643 pp.

Short AD. 1996. The role of wave height, period, slope, tide range and embaymentisation in beach classifications: A review. Rev. Chil. Hist. Nat. 69: 589-604.

Wright LD, Short AD. 1984. Morphodynamic variability of surf zones and beaches: A synthesis. Mar. Geol. 56: 93-118. http://dx.doi.org/10.1016/0025-3227(84)90008-2

Xue Z, Feng A, Yin P, Xia D. 2009. Coastal erosion induced by human activities: A northwest Bohai Sea case study. J. Coast. Res. 25: 723-733. http://dx.doi.org/10.2112/07-0959.1

Received August 2012, received in revised form July 2013, accepted August 2013. 